\title{
WORKING CAPITAL MANAGEMENT OF SOUTH AfRICAN RETAIL FIRMS
}

\author{
Elmarie Louw* \\ University of Pretoria
}

\author{
Leon Brümmer+
}

University of Pretoria

\author{
John Hall\# \\ University of Pretoria
}

Received: April 2015

Accepted: January 2016

\begin{abstract}
The way a firm manages its working capital can have a decisive influence on the firm's profitability and liquidity. In view of the prominent role that the retail industry plays in the South African economy, the purpose of this study was to investigate the effect of working capital management on the profitability of South African retail firms. Eighteen retail firms that were listed on the Johannesburg Securities Exchange for a period of nine years (2004-2012) were analysed. The findings show that a strategy of reducing investment in inventory and trade receivables, while increasing trade payables, appears to improve the profitability of South African retail firms. Inventory management seems to have the strongest statistically significant impact on a firm's profitability. Hence, it is recommended that retail firms implement advanced inventory management systems in order to optimise inventory levels and enhance profitability.
\end{abstract}

Keywords

Cash conversion cycle, Liquidity, Profitability, Retail Firms, Working capital management

*Mrs $\varepsilon$ Louw is a senior lecturer in the Department of Financial Management, University of Pretoria, South Africa. [elmarie.louw@up.ac.za]

\#Prof J Hall is professor in the Department of Financial Management, University of Pretoria, South Africa.

\#Prof L Brümmer is professor in the Department of Financial Management, University of Pretoria, South Africa. 


\section{INTRODUCTION}

The effect of working capital on a firm's liquidity and profitability is well known and formed the subject of many past research papers. However, ever increasing competition between firms put unprecedented pressure on profit margins in a time where corporate failures tend to increase, paving the way once again for a new look at working capital management in organisations.

Research on the management of working capital and its relation to liquidity and profitability was conducted (amongst others) by Deloof (2003), Eljelly (2004), Lazaridis and Tryfonidis (2006) and Palmer (2011). Although all these studies found a positive relationship between working capital and profitability, the strength of the relationship varies. A study by Erasmus (2010) as well as Smith and Fletcher (2009) have explored the effect of working capital management on the profitability of South African industrial firms. Their findings suggest that if such firms can reduce their investment in working capital, their profitability tends to increase. The present study will concentrate specifically on the South African retail industry for a number of reasons. Firstly, by its very nature, firms in the retail industry are heavily invested in working capital, making the management of working capital a priority for the management of this industry. Secondly, the South African retail industry is the fourth largest sector in the South African economy, growing in contribution from 11\% to 14\% from 2003 to 2011 (Gauteng Province Quarterly bulletin, 2012). Only a few studies, including those of Choudhary and Tripathi (2012) (on Indian firms) and Gosman and Kelly (2003) (on US data) have focused specifically on working capital management in the retail industry. These studies confirm that working capital management may have an effect on a firm's liquidity and profitability. To the researchers' knowledge, no prior studies have examined this aspect in the retail industry in South Africa.

This study therefore aimed to fill this gap, and to make a contribution to the body of existing knowledge, by investigating the effect of working capital management on the profitability of South African retail firms. The novel features of the present study is that working capital management will be analysed not only by looking at the effect of total working capital on profitability, but analysing the effect of inventory, debtors and creditors on a firm's profitability. In addition, the present study will use more profitability measurements that have been used in prior studies. The gross profit margin (GPM), return on assets (ROA), return on equity (ROE) and economic value added ( $\varepsilon V A)$ will be used as proxies for profitability in the present study.

This specific research methodology will bring about unique results. The refined results of this study about the influence of inventory, debtors and creditors on profitability can be used by the management of retail firms to optimise the profitability of their firms and to increase shareholder value creation. Further, analysts and potential investors in these firms can evaluate the effectiveness and the importance of working capital to the retail industry which will in turn assist them in their investment decisions.

The remainder of the article is divided into four parts. First, a literature review is presented of prior studies on the topic of working capital management. Based on the literature review, four hypotheses were formulated. Then the research design and methodology adopted in the present study are explained. Next, the results of the hypothesis testing are discussed. Lastly, conclusions are drawn on the findings of the study and its impact on future research is considered. 


\section{LITERATURE REVIEW}

Managing working capital is one of the most important functions in any organisation. Palmer (2011) found that $80 \%$ of the participating companies identified improving their working capital management as one of their top priorities, as maintaining an optimal level of working capital is a key performance indicator for a company.

One way to assess how well working capital is managed is to determine a firm's liquidity proficiency level. In the past, measures such as the current ratio and the quick ratio were used to evaluate a firm's liquidity. Several studies suggest that there are better measures to assess the working capital and liquidity of a firm (Eljelly, 2004; Erasmus, 2010; Smith \& Fletcher, 2009). For example, the cash conversion cycle (CCC) measures the length of time that working capital is tied up in a firm's operations. The CCC includes the main components of the net working capital cycle, namely trade receivables, inventories and trade payables.

Deloof (2003) analysed data on 1009 Belgian firms for the period from 1992 to 1996, to determine whether working capital management affected the firms' profitability. Working capital management was measured using the $\mathrm{CCC}$, and profitability was measured by the gross operating income. The results revealed a negative correlation between the number of days' accounts receivable, inventories, accounts payable and the gross operating income. Deloof (2003) concluded that the way in which working capital is managed does indeed affect the profitability of a firm. Moreover, Deloof (2003) found that shareholder value can be created if managers reduce the value of accounts receivable and decrease inventories to a reasonable minimum. The sample of the Deloof (2003) study included all sectors of the economy, therefore ignoring possible differences in working capital management between different types of firms or industries.

The management of working capital could differ between industries and it will be more informative to test the relationship between working capital management and profitability within one specific industry. Smith and Fletcher (2009) tested for cross-sectional influences on the working capital of South African industrial firms, looking at 103 companies listed on the JSE. Thirteen working capital measures were identified, namely the current ratio, the quick ratio, inventory turnover, accounts receivable turnover, accounts payable turnover, sales divided by net working capital, long-term loan capital divided by net working capital, accounts receivable divided by accounts payable, total current liabilities divided by gross funds flow, the CCC, the net trade cycle, the comprehensive liquidity index and the net liquid balance divided by total assets. By including 13 different variables, the authors manage to not only assess the overall the effect of working capital management on profitability, but also the effect of different components that forms part of working capital management. All except one of these 13 working capital measures indicated a significant industry effect. Smith and Fletcher (2009) therefore concluded that overall there is a significant sector effect in the working capital measures of listed South African industrial firms.

Another study which also focuses on the South African industrial sector was performed by Erasmus (2010) who tested the correlation between profitability and working capital management. He used ROA as the dependent variable to measure profitability, and the net trade cycle to measure working capital management. The results showed a strong negative relationship between a firm's net trade cycle and the firm's profitability. This finding suggests that firms with low levels of net current assets are more profitable. It is therefore important for management to understand the correlation between profitability and liquidity, and to maintain the optimal level of net current assets. 
Stability in the working capital investment and an improvement in profitability could create shareholder value. This concept was investigated by Eljelly (2004) whom examined the relation between liquidity and profitability, and the effect thereof on shareholders' value. A sample of 29 Saudi Arabian companies was selected from three different sectors, namely the agriculture, industrial and services sectors. Eljelly (2004) hypothesised that there is a negative correlation between liquidity and profitability, and this was indeed confirmed in his study. He also found that that company size and sector had an effect on profitability, with the exception of the services sector, where the focus is on the efficiency of asset use, rather than on the number of assets. Eljelly's (2004) results also indicated that firms that held excess inventory incurred unnecessary costs, resulting in lower profitability and will ultimately result in shareholders' value to decrease. Bellouma (2011) found similar results between working capital and profitability for Tunisian firms operating in the export industry.

A study performed by Barine (2012) investigated the effect of working capital management on profitability of Nigerian firms. Results suggested that an improvement of working capital management will not improve profitability. The study did however only include one year's financial results and as with the Deloof (2003) study, included all types of industries.

Gosman and Kelly (2003) analysed working capital management processes in the retail industry of the US, focusing on inventory management and payment policies. Some companies shift their inventory risk to their suppliers by implementing just-in-time (JIT) delivery systems. They reduce their investment in inventory further by implementing consignment procedures. When inventory is purchased as consignment stock, inventory can be on a retailer's shelves before it has been paid for. In that case, the risk of holding the title to the inventory lies with the supplier, and the purchase of the item and corresponding trade payable is only accounted for once the item is sold. According to Gosman and Kelly (2003), many large (in terms of total revenue) retailers, such as Wal-Mart, have implemented consignment procedures, especially since the 1990 s. Moreover, firms often arrange shipment of goods directly from suppliers to customers, decreasing inventory costs even more.

Gosman and Kelly (2003) note that, irrespective of the payment terms that large retailers are able to negotiate with their suppliers, they can pay outstanding accounts on whichever date they prefer, as suppliers do not want to lose their business and therefore do not implement harsh collection techniques. The study also suggests that retailers that hold power over their suppliers can improve their sales growth without additional investment in their working capital. However, such a policy empowers only the retailers, at the expense of the suppliers.

It is clear that inventory management is an important aspect of the retail industry and this lead to Choudhary and Tripathi (2012) investigating the impact of inventory management on the profitability of three Indian retail firms. They found that the management of working capital components differed even within a single sector, in this case the retail industry. Their results suggest that the different techniques used by the companies have different effects on financial indicators. Thus their findings on the relationship between inventory turnover and financial performance were inconclusive.

Various international studies have investigated the effect of working capital management on the profitability of firms (Barine, 2012; Bolek, Kacprzyk \& Wolski 2012; Deloof, 2003; Garcĩa-Teruel \& Martĩnez-Solano, 2007; Lazaridis \& Tryfonidis, 2006). Studies performed within a South African context have been focussing predominantly on the industrial sector (Erasmus, 2010 and Smith \& Fletcher, 2009). Some international studies focussed on the retail sector (Gosman \& Kelly 2003 and Choudhary and Tripathi 2012). However, there seems to be a gap in the existing literature as 
none of the studies focussed on the retail sector in South Africa. The present study aims to fill this gap.

Most of the findings from the prior studies discussed above indicated that a reduction of the investment in working capital will result in profitability to increase (Deloof, 2003; Erasmus, 2010; Eljelly, 2004; Lazaridis and Tryfonidis, 2006). However results from the Barine (2012) study suggested that a reduction in the investment in working capital will result in profitability to decrease. Several studies investigated the effect of changes in specific working capital components (inventory, trade receivables and trade payables) on the profitability of firms (Bellouma, 2011; Lazaridis \& Tryfonidis, 2006), and found that a reduction in inventory, trade receivables and/or increase in trade payables will improve profitability.

The present study aimed to investigate relationship(s) between working capital management and profitability in the South African retail industry. These relationships were investigated by means of hypothesis testing to establish whether a reduction in the investment in inventory, a reduction in the investment in trade receivables, or an increase in trade payables, or a combination of all three, results in an increase or decrease in the profitability of retail firms. The following hypotheses were tested:

- Hypothesis 1: The lower a firm's investment in working capital, the higher its profitability.

- Hypothesis 2: The lower a firm's investment in inventory, the higher its profitability.

- Hypothesis 3: The lower a firm's investment in trade receivables, the higher its profitability.

- Hypothesis 4: The higher a firm's investment in trade payables, the higher its profitability.

These hypotheses address the research question to achieve the goals of this study. The next section identifies the research method used to achieve the study's goals.

\section{DATA AND METHODOLOGY}

This section describes the research design and methodology used in the study, providing a rationale for the methodology and research procedures.

The data used in this study were obtained from inetBFA, a South African supplier of quality financial data. In 2013 when data was obtained for the current study there were 21 retail firms listed on the JSE. Three of these firms were newly listed and were excluded from the data sample. Of the 18 remaining retail firms, 15 firms were listed for 9 years or longer and it was therefore decided that the study will analyse data over a nine-year period, 2004 to 2012, to limit the amount of missing data. However, due to the inclusion of firms not being listed for the total period under review, missing data did exist. Of the 1539 data points, 69 were missing (4\%) which SPSS statistics data editor identified as 5 patterns of missing data. For each pattern of missing data identified, SPSS estimated the values using a multiple imputation model. The original sample of 18 was therefore increased to 108 ( 18 firms $\times 6$ (original data sample + 5 data samples for each missing pattern)). This procedure should not be seen as a limitation of the present study as the purpose of a multiple imputation model is not to re-create the individual missing values as close as possible to the true ones, but to handle missing data to achieve valid statistical inference (Schafer, 1997). 
The hypothesis testing aimed to determine the effect of the different working capital components on the profitability of retail firms. In the four hypotheses, a number of variables were identified and included in this study, as discussed below.

Working capital was represented by the CCC, AAI (average age of inventory), AAR (average age of receivables) and AAP (average age of payables) as the independent variables for the hypothesis testing. As discussed in the literature review, previous studies only included one profitability measure whereas the present study will include four. In the present study, profitability was measured using ROA (return on assets), ROE (return on equity), the GPM (gross profit margin) and EVA (economic value added). By using more than one profitability measurement, the results from the analysis could be refined, interpreted with greater detail and the recommendations from the results could be more applicable. In addition, two of the variables, namely ROE and EVA can be used as 'value indicators', giving wider applicability to the interpretation of the results, namely for analysts and potential investors as well, over and above for the management of the firm.

The calculations for the various independent variables were the following: return on average assets $(R O A)=$ profit available to ordinary shareholders $\div$ total assets; return on equity $(R O E)=$ profit available to ordinary shareholders $\div$ ordinary equity; gross profit margin $($ GPM $)=$ sales cost of sales $\div$ sales and Economic Value Added $(\varepsilon V A)=$ net operating profit after tax - (capital invested $\times$ weighted average cost of capital).

Panel data were used in the present study. The variables of each firm were analysed for each year for the total period under review, 2004 to 2012.

We estimated the following empirical models:

- Hypothesis 1 :

Profitability variable $=\beta_{0}+\beta_{1} C C C+\varepsilon$

- Hypothesis 2:

Profitability variable $=\beta_{0}+\beta_{1} A A I+\varepsilon$

- Hypothesis 3:

Profitability variable $=\beta_{0}+\beta_{1} A A R+\varepsilon$

- Hypothesis 4:

Profitability variable $=\beta_{0}+\beta_{1} A A P+\varepsilon$

In these equations, $\varepsilon$ represents an error term. The profitability variable represents ROA, ROE, the GPM or EVA; therefore the empirical model was repeated for each profitability variable.

A Pearson correlation calculation was performed to establish whether the variables were correlated with each other, and to determine the nature of any correlation. Multiple linear regression analysis was performed, because the data set was based on firm-specific observations over time (2004 to 2012) and more than one explanatory variable was included in the study. The empirical results are discussed in the next section.

\section{EMPIRICAL RESULTS AND DISCUSSION}

This section contains an analysis and a discussion of the results from the statistical tests performed on the data sample. 


\subsection{Descriptive statistics and correlation analysis}

The descriptive statistics presented in TABLE 1 relate to the total sample, summarizing the variables with their minimum, maximum, median and mean values, as well as the standard deviation for each variable.

TABLE 1: Descriptive statistics

\begin{tabular}{lcccccc}
\hline & $N$ & Min & Max & Median & Mean & $\begin{array}{c}\text { Standard } \\
\text { deviation }\end{array}$ \\
\hline CCC days & 108 & -21 & 271 & 26 & 58 & 78 \\
\hline AAl days & 108 & 11 & 205 & 69 & 69 & 31 \\
AAR days & 108 & 7 & 309 & 302 & 75 & 77 \\
AAP days & 108 & 48 & 136 & 83 & 85 & 23 \\
ROA \% & 108 & 1 & 38 & 17 & 19 & 7 \\
ROE \% & 108 & 5 & 60 & 31 & 31 & 14 \\
GPM \% & 108 & 8 & 55 & 26 & 30 & 13 \\
\hline EVA R & 108 & -50235 & 974978 & 243027 & 371418 & 320396 \\
\hline
\end{tabular}

Source: Authors' analysis

The wide range of the CCC (-21 days to 271 days) was expected for the data sample. The CCC of a food retailer selling goods predominantly on a cash basis was expected to have a very short even negative CCC, whereas a retailer of luxury items or durable goods where sales could take place on credit, would have a longer CCC.

The range of the AAI (11 days to 205 days) was also large and contributed to the large range of the CCC noted above. The AAI would depend on the type of retailer; for example, a low cost household items retailer selling fast moving consumer goods versus a retailer of durable goods where stock sells relatively slower.

The range of AAR (seven days to 309 days) was very large, even larger than the range of the AAI. It must be remembered that several firms included in the sample sell goods mainly on a cash basis, resulting in a low AAR, whilst firms that sells more durable goods must in many cases grant credit, resulting in a relative high level of debtors with a long debtor's collection period. This study assumed that firms that do sell goods on credit try to minimize their AAR, resulting in a shorter CCC.

The range of AAP (48 days to 136 days) was smaller than the CCC, AAI and AAR ranges. What was however notable, was the difference in days between the AAI, AAR and AAP. The fact that the mean of the AAP was longer than that of the AAI and ARR is an indication that creditors are used to finance the inventory and debtors in the retail sector.

The descriptive statistics above suggest that the range of the values of the variables in the data sample was large for both the profitability measures and the working capital measures. This large range of values within the various measures was somewhat surprizing, as the total sample consists of firms in the retail industry. To determine the relationship between these measures and whether 
working capital measurements can be used to predict profitability, the data were analysed in more detail.

A Pearson correlation calculation was performed to establish whether the variables are correlated with each other, and to determine the direction of any correlation. The correlations are set out in TABLE 2.

TABLE 2: Correlation between the CCC and the profitability measures

\begin{tabular}{lccccc}
\hline & $C C C$ & $R O A$ & $R O E$ & $G P M$ & EVA \\
\hline CCC & 1.00 & & & & \\
ROA & 0.16 & 1.00 & & & \\
ROE & $-0.49 * \star$ & $0.26 * \star$ & 1.00 & & \\
GPM & $0.44 * \star$ & $0.39 * \star$ & $-0.33 * \star$ & 1.00 & \\
EVA & $-0.21 *$ & $0.26 * \star$ & $0.66 * \star$ & 0.00 & 1.00 \\
\hline
\end{tabular}

Source: Authors' analysis

*Significant at a $5 \%$ level. **Significant at a $1 \%$ level.

There was no multicollinearity between the independent variables and as the objective of this study was to investigate the relationship between the independent and dependent variables, the relationship between the independent variables will not be discussed further.

With regard to the CCC, a correlation was found with the ROE and the GPM, and a relative small correlation was noted between the CCC and EVA. The two relative strong correlations (ROE and the GPM with the CCC) indicate opposite relationships; the CCC and ROE are negatively correlated, but the CCC and GPM are positively correlated. It can therefore be concluded that a decrease in the CCC results in a decrease in the GPM and a decrease in the CCC results in an increase in both ROE and EVA.

The negative correlation between the CCC and ROE, and between the CCC and $E V A$, confirms that if a firm reduce its investment in working capital, the excess funds are invested in more profitable and value-creating investments. ROE and EVA are both value creation indicators which, based on the results of the present study, reacts positive to a reduction in the CCC. In addition, the ROE and EVA are also positively correlated with each other, supporting a 'double movement' of profitability and value creation in the same direction.

Based on the Spearman correlation coefficients, with regard to the correlation of AAI, AAR and AAP with profitability measures, it was noted that AAl is positively correlated with only the GPM. The rest of the predictors are negatively correlated with AAI. The AAI and GPM may be positively correlated because, if a firm tries to reduce its inventory levels, it might sell its inventory at reduced selling prices resulting in a reduced gross profit margin.

A negative correlation between AAR and ROE was confirmed. However, both ROA and the GPM were positively correlated with AAR, contrary to the stated hypothesis. Hence, if AAR should decrease, so would ROA and the GPM. If a firm reduces its trade receivables by implementing more stringent credit standards, sales may be reduced, and this may result in decreased profitability margins. The reduction in trade receivables may also result in a decrease in total assets. However, if profit decreases more than total assets, ROA will decrease. A decrease in sales demand may force a firm 
to sell goods at reduced selling prices, which would cause the GPM to decrease, together with the decrease in trade receivables.

AAP has a significant positive correlation with all the profitability variables. If management purchases higher amounts of inventory at reduced prices from creditors, it will increase the GPM by reducing costs. Buying more goods on credit would increase trade payables. Reducing the cost of goods could result in firms' reducing their selling prices, which would result in sales increasing, and would enhance the firm's profit margins.

In summary, the relationship between the CCC, AAI AAR and AAP and the GPM is positive. Negative correlations were noted for the $C C C$ with ROE and $E V A$, and for AAI with ROE, EVA and ROA. AAR was negatively correlated with ROE. AAP was positively correlated to all of the profitability variables.

To further test the relationship between the variables and address the hypotheses derived in the literature section, a multiple regression analyses were performed. The results are discussed below.

\subsection{Multiple regression analyses}

Hypothesis 1 aims to determine whether a reduction in the investment in net working capital results in increased profitability. The results of the regression analysis are presented in TABLE 3.

TABLE 3: Multiple regression analyses between the CCC and profitability

\begin{tabular}{lcccccccc}
\hline & \multicolumn{2}{c}{ ROA } & \multicolumn{2}{c}{ ROE } & \multicolumn{2}{c}{ GPM } & \multicolumn{2}{c}{ EVA } \\
& Estimate & t-value & Estimate & t-value & Estimate & t-value & Estimate & t-value \\
\hline Intercept & 17.922 & 20.25 & 35.914 & 23.761 & 25.614 & 18.861 & 421943 & 11.171 \\
CCC & 0.161 & 1.675 & $-0.492 \star \star$ & -5.82 & $0.436 \star \star$ & 4.987 & $-0.212^{*}$ & -2.236 \\
R & 0.026 & & 0.242 & & 0.190 & & 0.045 & \\
Adjusted R & 0.017 & & 0.235 & & 0.182 & & 0.036 & \\
Fisher Ftest & 2.806 & & 33.870 & & 24.871 & & 5.001 & \\
\hline
\end{tabular}

Source: Authors' analysis

*Significant at a $5 \%$ level. **Significant at a $1 \%$ level.

Regression models:

$R O \varepsilon=35.914-0.492(C C C)+\varepsilon$

$\mathrm{GPM}=25.614+0.436(\mathrm{CCC})+\varepsilon$

$\varepsilon V A=421943-0.212(C C C)+\varepsilon$

Of the four profitability predictors, three were statistically significant: ROE $(p<0.01)$, GPM $(p<.01)$ and EVA $(p<.05)$. The adjusted $\mathrm{R}^{2}$ was the strongest for ROE, at $23.5 \%$. The $\mathrm{R}^{2}$ was $18.2 \%$ for the GPM. It was weakest for $\varepsilon V A$, at $3.6 \%$.

The model suggests that an increase in the $C C C$ may result in a statistically significant decrease in ROE $(\beta=-0.492)$ and in EVA $(\beta=-0.212)$. Hypothesis 1 postulates that an increase in the CCC would result in a decrease in profitability. This hypothesis was accepted, indicated by the decline in ROE and EVA. However, an increase in the CCC results in an increase of the GPM. This suggests that if firms manage to decrease the CCC, the GPM will also decrease, but ROE and EVA will 
increase. A reason for the different directions of the correlations between the profitability predictors may be that retail firms manage their CCCs by decreasing their selling prices to increase sales, which results in a decreased GPM. Increased sales result in an increase of other profitability measures (ROE and $\varepsilon V A$ ). It can therefore be concluded that a reduction in the CCC has a positive effect on profitability (ROE) and on a firm's value (EVA). Hypothesis $l$ is therefore accepted: a decrease in the $C C C$ results in increased profitability and value creation.

Hypothesis 2 addresses the relationship between AAI and profitability. A negative correlation was expected, because, if a firm manages to reduce its inventory levels, the investment in working capital should decrease, resulting in increased profitability. The results of the regression analyses are set out in TABLE 4 .

TABLE 4: Multiple regression analyses between AAI and profitability

\begin{tabular}{lcccccccc}
\hline & \multicolumn{2}{c}{ ROA } & \multicolumn{2}{c}{ ROE } & \multicolumn{2}{c}{ GPM } & \multicolumn{2}{c}{ EVA } \\
& Estimate & t-value & Estimate & t-value & Estimate & t-value & Estimate & t-value \\
\hline Intercept & 19.882 & 11.299 & 51.372 & 19.699 & 13.828 & 5.661 & 733685.8 & 11.198 \\
AAI & -0.065 & -0.668 & $-0.645^{\star *}$ & -8.7 & $0.568 * *$ & 7.099 & -0.507 & -6.055 \\
R & 0.004 & & 0.417 & & 0.322 & & 0.257 & \\
Adjusted R & -0.005 & & 0.411 & & 0.316 & & 0.250 & \\
Fisher F test & 0.446 & & 75.696 & & 50.396 & & 36.661 & \\
\hline
\end{tabular}

Source: Authors' analysis

*Significant at a $5 \%$ level. **Significant at a $1 \%$ level.

Regression models:

$\mathrm{RO} \varepsilon=51.372-0.645(\mathrm{AAI})+\varepsilon$

$\mathrm{GPM}=13.828+0.568(\mathrm{AAI})+\varepsilon$

The only significant correlation between AAI and profitability measurements was that of ROE $(p<.01)$ and GPM $(p<.01)$. The adjusted $\mathrm{R}^{2}$ was $41.1 \%$ for ROE and $31.6 \%$ for the GPM, indicating a relative strong predictive power of AAI.

The results from this analysis show that, if the AAI decreases, so does the GPM $(\beta=0.568)$. A firm may sell goods at reduced selling prices to decrease its investment in inventory, but the gross profit then also decreases due to the reduced selling prices and profit margins. Selling better quality products with higher cost prices may not increase the profit margin as the profit margin is compromised by lowering the selling price to sell inventory faster. Inventory may decrease because items are sold faster, but the gross profit also decreases due to reduced selling prices or higher cost of sales (reducing the profit margin).

The relationship between AAI and ROE indicates that for every one unit reduction in AAl, the ROE increases by 0.645 units. This confirms that when firms reduce their inventory levels by adjusting their gross profit margin, they sell more items. In that case, the results of the present study indicated that profitability, as measured in terms of ROE, increases.

Based on the above findings, it can be concluded that retail firms manage their investment in inventory by lowering the selling price (and gross profit margin), which could result in an increased 
ROE. Hypothesis 2 is therefore accepted, namely that reducing investment in inventory improves a firm's profitability (ROE).

Hypothesis 3 investigates the relationship between debtors, as represented by the AAR, and profitability. A negative correlation is expected, because if a firm can reduce its AAR, the CCC should decrease, resulting in increased profitability. The results of the regression analyses are set out in TABLE 5.

TABLE 5: Multiple regression analyses between AAR and profitability

\begin{tabular}{lcccccccc}
\hline & \multicolumn{2}{c}{ ROA } & \multicolumn{2}{c}{ ROE } & \multicolumn{2}{c}{ GPM } & \multicolumn{2}{c}{ EVA } \\
& Estimate & t-value & Estimate & t-value & Estimate & t-value & Estimate & $t$-value \\
\hline Intercept & 29.288 & 1.482 & 126.825 & 7.614 & 25.130 & 16.036 & 389028.4 & 9.005 \\
AAR & $0.233 *$ & 2.470 & $-0.318 * \star$ & 3.453 & $0.373 * \star$ & 4.145 & -0.057 & -0.584 \\
$\mathrm{R}^{2}$ & 0.054 & & 0.101 & & 0.139 & & 0.003 & \\
Adjusted R & 0.045 & & 0.093 & & 0.131 & & -0.006 & \\
Fisher F test & 6.100 & & 11.927 & & 17.177 & & 0.341 & \\
\hline
\end{tabular}

Source: Authors' analysis

*Significant at a $5 \%$ level. **Significant at a $1 \%$ level.

Regression models:

$\mathrm{ROA}=29.288+0.233 \mathrm{AAR}+\varepsilon$

$R O \varepsilon=126.825-0.318 \mathrm{AAR}+\varepsilon$

GPM $=25.130+0.373 \mathrm{AAR}+\varepsilon$

The regression analyses show that ROA $(p<.05)$, ROE $(p<.01)$ and the GPM $(p<.01)$ are statistically significant predictors of changes in AAR. The adjusted $R^{2}$ was $5.4 \%$ for ROA, $9.3 \%$ for ROE and $13.1 \%$ for the GPM, all three indicating a weak statistical power in predicting AAR. The GPM was the best predictor of AAR, as the adjusted $R^{2}$ was the highest. Both ROA $(\beta=0.233)$ and the GPM $(\beta=0.373)$ indicate that if trade receivables decreases, so does ROA and the GPM. However, a decrease in trade receivables results in an increased ROE $(\beta=-0.318)$.

Previously, for Hypothesis 2, a positive relationship was found between inventory levels and gross profit. Now, for Hypothesis 3, a positive relationship was also found between trade receivables and gross profit. For every one unit decrease in AAR, the GPM decreased by 0.373 units. One way to reduce trade receivables may be to increase cash sales by offering a cash discount. Products are then sold at a lower selling price, but trade receivables decreases as fewer items are sold on credit. In principle, a reduction in selling prices results in a decreased gross profit margin. This is confirmed by the results of the present study; trade receivables and gross profit are positively correlated.

The results of the present study indicate that the direction of the relationship (positive or negative) between AAR and the profitability predictors is different for ROA and ROE. The regression analysis of the present study shows that as AAR decrease, so did ROA. A possible reason for this may be as follows: if a cash discount were granted, even though trade receivables would decrease, cash levels would increase due to the increase in cash sales. The increase in cash sales 
would result in an increase in cash balances, therefore increasing total assets, which could result in ROA's decreasing $(\beta=0.233)$. The increase in profit could, however, result in an increase in ROE $(\beta=-0.318)$. Therefore Hypothesis 3 , namely that a reduction in AAR will result in an increase in profitability, is accepted with regard to ROE, but rejected with regard to the other profitability measures (the GPM and ROA).

Hypothesis 4 addresses the relationship between trade payables and profitability. When calculating the CCC of a firm, an increase in AAP will result in a decrease in the CCC and a decrease in the CCC should, according to Hypothesis 1 , result in increased profitability. Therefore an increase in trade payables could result in increased profitability. The results of the regression analyses in this regard are set out in TABLE 6.

TABLE 6: Multiple regression analyses between AAP and profitability

\begin{tabular}{lcccccccc}
\hline & \multicolumn{2}{c}{ ROA } & \multicolumn{2}{c}{ ROE } & \multicolumn{2}{c}{ GPM } & \multicolumn{2}{c}{ EVA } \\
& Estimate & t-value & Estimate & t-value & Estimate & t-value & Estimate & t-value \\
\hline Intercept & 76.933 & 12.804 & 96.623 & 18.927 & 4.408 & 1.127 & 524342.5 & 4.425 \\
AAP & 0.143 & 1.486 & -0.232 & -2.461 & $0.545 \star \star$ & 6.684 & -0.129 & -1.336 \\
R & 0.020 & & 0.054 & & 0.296 & & 0.017 & \\
Adjusted R & 0.011 & & 0.045 & & 0.290 & & 0.007 & \\
Fisher F test & 2.208 & & 6.055 & & 44.673 & & 1.786 & \\
\hline
\end{tabular}

Source: Authors' analysis

*Significant at a $5 \%$ level. **Significant at a $1 \%$ level.

Regression model:

$\mathrm{GPM}=4.408+0.545 \mathrm{AAP}+\varepsilon$

The only significant profitability measure related to AAP is the GPM with an adjusted $R^{2}$ of $29 \%$. The model suggests that for every one unit increase of AAP, the GPM increased by 0.545 units. The average age of payables can be increased if better terms are negotiated with suppliers. The retail firms included in this study are relatively large firms and, as Gosman and Kelly (2003) have found, large firms can, when suppliers cannot afford to lose their business, increase the average age of payables without formally negotiating better terms. This could however have a negative impact on the supply chain to the firm.

The results from the analysis of ARR and profitability measures suggest that retail firms negotiate credit terms which may include reduced purchase prices, as an increase in trade payables results in an increase in the GPM. However, the effect of changes in trade payables on other profitability measures was statistically insignificant. Purchasing goods from a supplier has a direct effect on the retail firm's cost of sales, and therefore on the firm's gross profit margin. Therefore it was expected that a change in the investment in trade payables would affect a firm's GPM. Perhaps a change in trade payables does not have a significant effect on the other profitability measures because the firms in this study do not utilise the benefits of improved credit terms to such an extent that other profitability measurements is improved or affected, and that all parties in the supply chain benefit from the payment terms; both the retail firm (lower purchase prices) and the supplier (earlier payments and higher sales volumes). 


\subsection{Implications of the results}

The results of the present study indicated that GPM was the best profitability predictor, as it reacted statistically significant to all four of the working capital components, namely the CCC, AAI, AAR and AAP. ROE was statistically significant in predicting the CCC, AAI and AAR, and had the highest adjusted $R^{2}$ in predicting the CCC and AAI. Finally, EVA and ROA were the weakest predictors, as each of these profitability measures was only statistically significant for one of the working capital components. These results are illustrated in FIGURE 1.

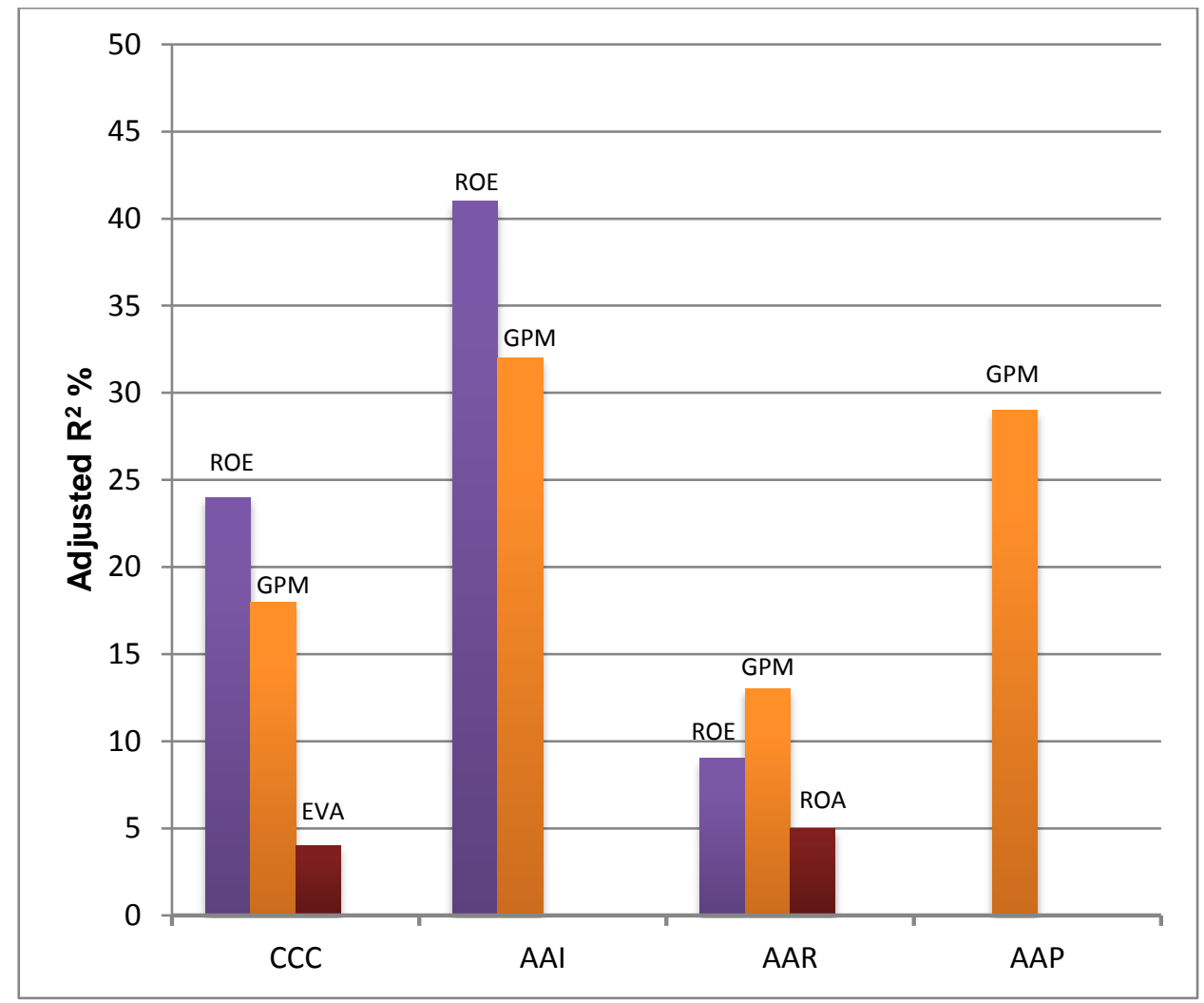

\section{FIGURE 1: عffect of working capital on profitability}

Source: Author's analysis

Lazaridis and Tryfonidis (2006) found a negative correlation between the CCC and GPM of firms listed on the Athens stock exchange, whereas the present study found a positive correlation between the CCC and GPM. The results of the present study indicated a strong relationship between all four working capital measures and the GPM, confirming the relationship between working capital and profitability. The implication for management of this finding is that they should consistently try to reduce working capital; the quest for zero working capital must continue and will have an definite positive effect on profitability. Creditors should be used to finance the stock and debtors as far as possible. However, what is of greater importance for management is the individual working capital's components (inventory, debtors and creditors) whose relation to profitability will vary, especially for retail firms. The main operating activity of retail firms is selling inventory items. From the literature analysis it was expected that any change in inventory 
should have a relative strong effect on the GPM, the figure 'closest' to inventory, directly influenced by inventory.

Bellouma (2011) found that a reduction in inventory increased the profitability of Tunisian firms. In the present study, even though AAI and the GPM are positively correlated, the correlation between AAI and ROE is negative. The latter a finding similar to Bellouma's (2011), namely that decreasing investment in inventory improves a firm's profitability (ROE). Changing inventory levels will have effects on different profitability measures. Management should evaluate the differing effects on profitability. Careful analysis of the firm specific factors and expense items that could have an effect on different profitability measures must be conducted in order to optimise the relationship between inventory and profitability. For example, firms must be cautious on which products (inventory items) they allow a discount as the through flow to profit centres can vary.

Large retailers included in this study (Checkers/Shoprite, Massmart, Spar, and Pick $n$ Pay) predominantly have cash sales. For this reason, trade receivable management is not as important to these retailers as inventory management. This was confirmed by the results of the present study and explains the relative weak explanatory power of AAR for the profitability of these firms. For retail firms that do sell on credit, the implication of this finding is that increased sales and debtors could result in improved profitability (as measured by the ROE).

Both Deloof (2003) and Lazaridis and Tryfonidis (2006) found a negative correlation between investment in trade payables and gross profit, and they concluded that less profitable firms take longer to pay their suppliers. In the present study, a positive correlation was found between trade payables and profitability (GPM), indicating that firms may successfully take advantage of terms provided by suppliers, and negotiate prices and credit terms to benefit both the retailer and the supplier. In this regard management of firms may carefully design and implement an efficient supply chain system for their firm. Good supplier relations with credit terms that are adhered to will be to the benefit of both parties. Management must seek payment discounts from their suppliers to improve profit margins. In addition, most retails firms do have cash readily available, making the practice of seeking discounts on early creditor payments a worthwhile practice.

\section{CONCLUSION}

This study's objective was to investigate the relationship between working capital management and the profitability of South African retail firms. The effect of such a reduction on profitability was tested with regard to net working capital and the three components of the CCC, namely inventory, trade receivables and trade payables. Profitability was measured using ROA, ROE, the GPM and EVA.

It was expected that if investment in working capital could be reduced, profitability would increase. A reduction in the CCC can be accomplished by reducing investment in inventory and trade receivables, and increasing investment in trade payables. The results reveal that reducing inventory levels has the highest statistically significant impact on a firm's profitability (as measured by the ROE) and thus appears to be a useful strategy. This finding emphasises the importance of inventory management for a retail firm. Reducing trade receivables does not have as high an impact on a firm's profitability as a reduction of the investment in inventory. The reason for this may be that retail firms predominantly sell goods for cash. Thus, although reducing investment in trade receivables results in increased profitability, the increase is not as 
significant. Moreover, increasing investment in trade payables increases only the gross profit margin, and none of the other profitability measures is affected. A possible reason for the effect on the gross profit margin is the direct effect that the cost of items (which is used to calculate the gross profit margin) has on trade payables. The level of trade payables did not display statistically significant results in respect of the other profitability predictors. It could be argued that the firms included in this study did not necessarily negotiate better credit terms with their suppliers, or that terms were set to benefit all parties in the supply chain. Hence, it can be concluded that South African retail firms manage their CCC by implementing advanced inventory management, and do so by reducing their inventory levels to a minimum. This brings to the forefront the need for a reliable ordering and inventory management system where the relationship between the purchase prices, profit mark-up and selling price of each item is accurately stated and closely monitored. It is recommended that firms should continuously monitor the profit margins of their sales as the cost of investing in debtors could outweigh the benefits from increased (credit) sales, especially where firms have a relative high cost of financing or where the country is in an upward interest rate cycle. It is further recommended that larger firms must implement inventory consignment procedures and by doing this they will successfully reduce the risk associated in holding high levels of inventory. The effect of such procedures on a firm's profitability can be positive.

Based on the findings in the present study, it is recommended that future research focus specifically on the effectiveness of inventory management and its possible effects on the profitability of firms in other sectors. Future research could look at other sectors in South Africa, for instance, the manufacturing or the services sectors, examining, for example, software manufacturers and healthcare providers. Such future studies might compare working capital management techniques in the retail sector with that in other sectors. The effect of working capital management on profitability can also be established for sectors other than the retail sector. The financing of working capital can also affect a firm's profitability and may be analysed in future research.

The results from this study confirms that effective management of working capital will improve a firm's profitability and increase shareholders' wealth, which is the ultimate goal of any firm.

\section{LIST OF REFERENCES}

Barine, M.N. (2012). Working capital management efficiency and corporate profitability: Evidence from quoted firms in Nigeria. Journal of Applied Finance \& Banking, 2(2), pp. 215-237.

Bellouma, M. (2011). The impact of working capital management on profitability: The case of small and medium-sized export companies in Tunisia. Management International, 15(3), pp. 71-118.

Bolek, M., Kacprzyk, M. \& Wolski, R. (2012). The relationship between economic value added and cash conversion cycle in companies listed on the WSE. Financial Internet Quarterly 'e-Finance', 8(2), pp. 110 .

Choudhary, H. \& Tripathi, G. (2012). An analysis of the inventory turnover and its impact on financial performance in Indian organized retail industry. Journal of Services Research, 12(1), pp. 43-64.

Cohen, J. (1988). Statistical Power Analysis for the Behavioural Sciences. $2^{\text {nd }}$ edition. Hillsdale, NJ: Lawrence Erlbaum. 
Dash, M. \& Hanuman, R. (2009). A liquidity-profitability trade-off model for working capital management. Available: http://ssrn.com/abstract=1408722. (Accessed 250 ctober 2012).

Deloof, M. (2003). Does working capital management affect profitability of Belgian firms? Journal of Business Finance \& Accounting, 30(3) \& (4), pp. 573-587.

Eljelly, A.M.A. (2004). Liquidity-profitability tradeoff: An empirical investigation in an emerging market. International Journal of Commerce and Management, 14(2), pp. 48-61.

Erasmus, P.D. (2010). The relationship between working capital management and profitability for South African listed industrial firms. The Business Review, Cambridge, 15(1), pp. 2-10.

Garcĩa-Teruel, P.J. \& Martĩnez-Solano, P. (2007). Effects of working capital management on SME profitability. International Journal of Managerial Finance, 3(2), pp. 164-177.

Gauteng Province. (2012). The retail industry on the rise in South Africa. Gauteng Province Quarterly Bulletin, April-June, pp. 1-39.

Gosman, M. \& Kelly, T. (2003). Working-capital efficiencies resulting from large retailers' power. Commercial Lending Review, 18(2), pp. 25-31.

Lazaridis, I. \& Tryfonidis, D. (2006). Relationship between working capital management and profitability of listed companies in the Athens stock exchange. Journal of Financial Management and Analysis, 19(1), pp. 26-35.

Palmer, B. (2011). Where is your working capital today? Business Credit, 113(8), pp. 40-41.

Schafer, J.L. (1997). Analysis of incomplete multivariate data, New York: Chapman and Hall.

Smith, M.B. \& Fletcher, L. (2009). Factors influencing working capital management in South Africa. Management Dynamics: Journal of the Southern African Institute for Management Scientists, 18(3), pp. 15-24. 